\title{
HERITAGE CONCERNING THE USAGE OF WATER RESOURCES IN THE DEFENCE SITES OF ANCIENT ROMAN EMPIRE
}

\author{
D. CONSTANTINESCU \& B.A. CARLAN \\ Faculty: Materials Science and Engineering, University Politehnica of Bucharest, Romania.
}

\begin{abstract}
The evolution of historic sites was influenced not only by socio-political events, but also by the evolution of the technological and economical activities, in connection with the particularities of the environment and climate changes, for a period of time. The methodologies regarding the storage and the transport of the water, necessary for the supplying for the ancient cities and fortresses, established during the pre-Roman civilization, were transferred to the Greek and Roman civilizations and, further, to the ones who inherited their constructions and technologies. In the researches, we have in view the well-known antique cities such as Troy, Roman sites on the Rhine River, Augusta Raurica, Roman Byzantine sites on the Danube River, Sucidava, Ulpia Oescus and Capidava.

Using the documents and results from the field investigations, the particularities regarding the water conservation and transportation in the ancient Wilusa (Ilion, Troy), and the transfer of water to the Romans and the extent of the huge area between the Aegean Sea, Danube River and the Rhine River are presented. In the article, we analyse the localization of water resources and the technologies used for water transportation and storage. The pictures taken on the field, maps and models of reconstitution of the existent damaged constructions are also presented.

The authors consider the article as only the first step in the analysis of the evolution of the water resources used by the ancient establishments located in the areas mentioned above. The elements of the water supply sources that were taken for consideration will be analysed using 'the environmental engineering science glasses'.
\end{abstract}

Keywords: environment, field investigation, fortress, technology, water.

\section{INTRODUCTION}

Water is a very important strategic resource for all inhabitants, civilians or military personnel, of the fortresses, castles or cities. If, during the peacetime, the supplies of the water was not a very difficult problem, during the periods of conflicts, wars and sieges or during remarkable changes of the climate, the water resource could be the border between life and death.

The secret about the source of water was very well kept and, at the same time, the techniques used in order to obtain water were very ingenious. For example, the authors have remarked [1] that the most disputed and mysterious vestige of the historical site of Sucidava, located on the Danube River, named also 'The Secret fountain', is an underground construction with two components: the shaft, at a depth of about $18 \mathrm{~m}$ from the ground level of the city, and an access corridor $26 \mathrm{~m}$ long, which descends to a source inside the defence site. In the late 6th Century, the water supply of Sucidava military garrison was more problematic than in the previous centuries, due to the possible changes in the climate and the environment which might have reduced the water level.

But which is the origin of these technologies, and how were they developed and transmitted along the centuries or millennia? How effective were they? It seems that the origin of many technologies was the Troy, the ancient Ilion, Wilusa.

Manfred Korfmann [2] shows that Emperor Constantine the Great (306-337) has first chosen Ilion as a location for his new capital of the Byzantine Empire, and Byzantium was 
chosen only later, which he then renamed Constantinople. It seems that the Romans, who were very proud to be the followers of the Trojans, have adopted many Hittite or Trojan technologies. We only have to remind that the same Emperor Constantine has paid a special attention to the cities and fortifications on the Danube River. The construction of the bridge from Sucidava to Ulpia Oescus is only one example [1] (Tudor [3, 4]).

\section{TROIA - A BRIDGE BETWEEN THE HITTITE EMPIRE AND THE DANUBE}

Wilusa, Troia, was in the middle of the Hittite Empire, and it is not very clear if it was a vassal or a leading city $[2,5,6]$ (Fig. 1 ).

The capital of the Hittites was at Hattusa in the middle of Asia Minor and Wilusa was at the western extremity, near the sea.

As early as the 3rd Century BCE, Rome began to acclaim its Trojan descend - as a mother of the renowned hero Aeneas, who led the surviving Trojans to Latium where they settled and established the lineage of the Roman population.

Troy was much more than a focus serving to legitimize political actions. The history of Troy became one of the foundation stones of the Greek and Roman civilizations, the heart of the culture of the ancient world $[2,7,8]$. In this case, it is very normal that the Romans, the Greeks and later the Byzantines learned to use many technologies of the Trojans.

Wherefrom does the name of this ancient bridge come? The south territory of the Sea of Marmara was called Troas or Troad in ancient times (Fig. 2). Many ancient cities were in this area, and probably Troy was the most important.

It may well be possible that this ancient site took the name from the two kings Tros and Ilos, proposes Mustafa Aşkin in his book [6].

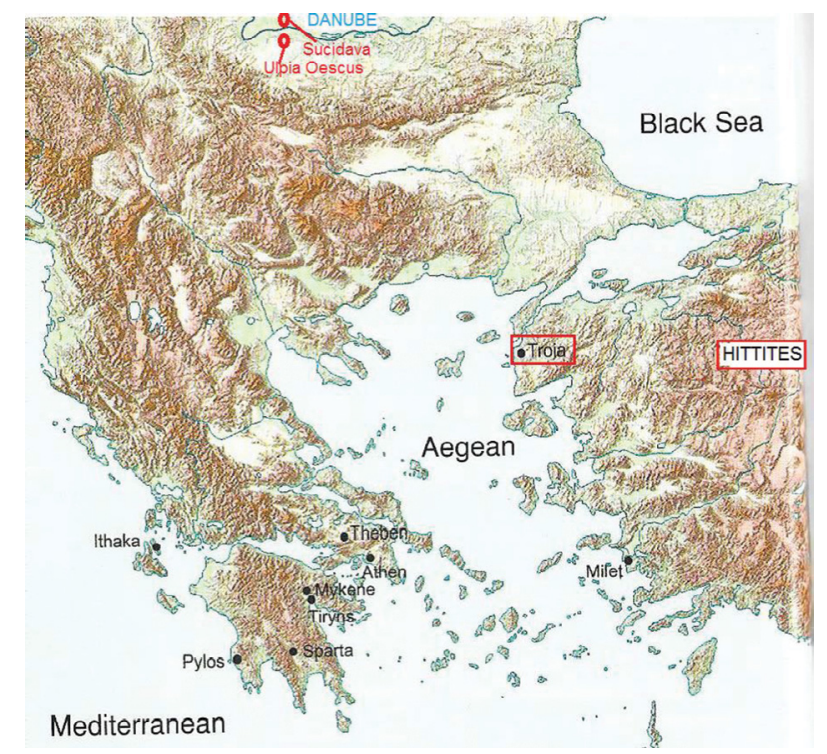

Figure 1: The Aegean realm, home of the Myceneans and Trojans (partially under control of the Hittites). (After Topography of the Ancient Word Mapping Center, University of North Carolina [2]). Note the potential of Troy as a bridge between Europe and Asia [2]. 


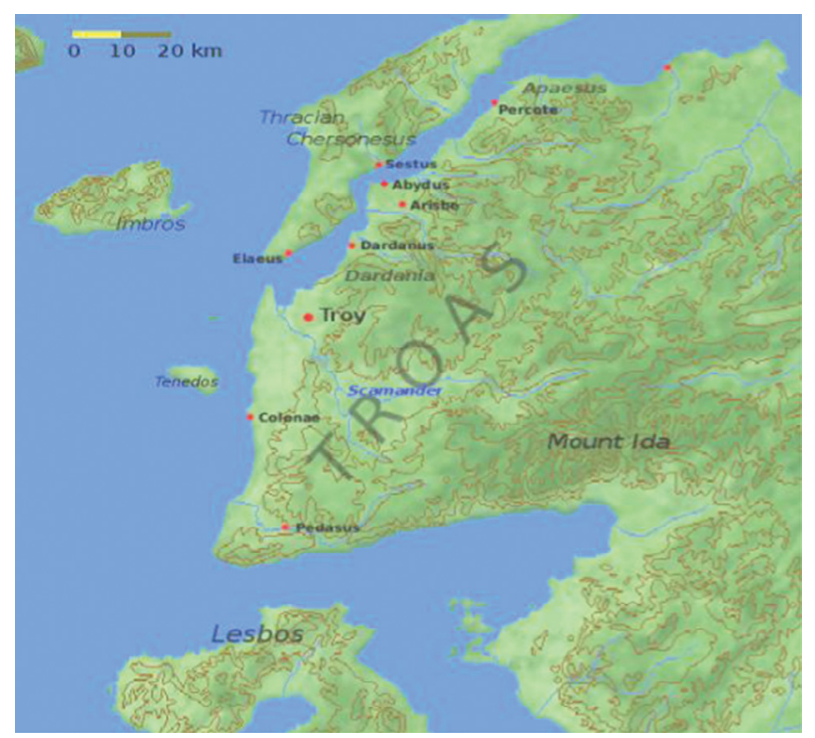

Figure 2: Troas territory, Mt Ida and part of Thracian land (transferred from Wikipedia, Dbachman, 2007).

\section{WATER RESOURCES FOR TROY}

During the normal peacetime the inhabitants of Troas did not have problem concerning the supply of water. The sources of water were the freshwater streams and the rivers.

The most important were probably Scamander, with the springs in Mount Ida and Simois (Fig. 3).

A cave (located in the area of the lower city, not totally excavated) and a basin were a source of a stream that connected with Scamander River. During the wartime or emergency time there were wells and cisterns built inside the defence system.

The water problem during the Roman time was solved by terracotta pipelines and aqueducts. An impressing aqueduct can be observed today at $12 \mathrm{~km}$ from Troy, in Kemerdere. It is a water system for the New Ilion. At Ilion, Troy, an ingenious system was used for the water collection and storing. In the southwest of the lower city an artificial cave with underground tunnels (160 m length) collected the rainwater. Probably an underground water source existed too. The Romans have used a similar technology later, not only for the fortresses located on Danube River, but also for the fortresses on Rhine River. In Fig. 4, after Korfmann [2], the plan of the water cave and the tunnels in Troy is presented.

In Fig. 5, a section of the tunnel and of the basin which collected the water and then extracted using the shafts is presented.

The excavations of the tunnel were open between 1997 and 2001 [2] in the area of the lower town and offered an impressing image of the tunnels and of the applied technique.

In Figs. 6 and 7, the pictures of the entrance and the interior of the tunnel, in siliceous rock, are presented. 


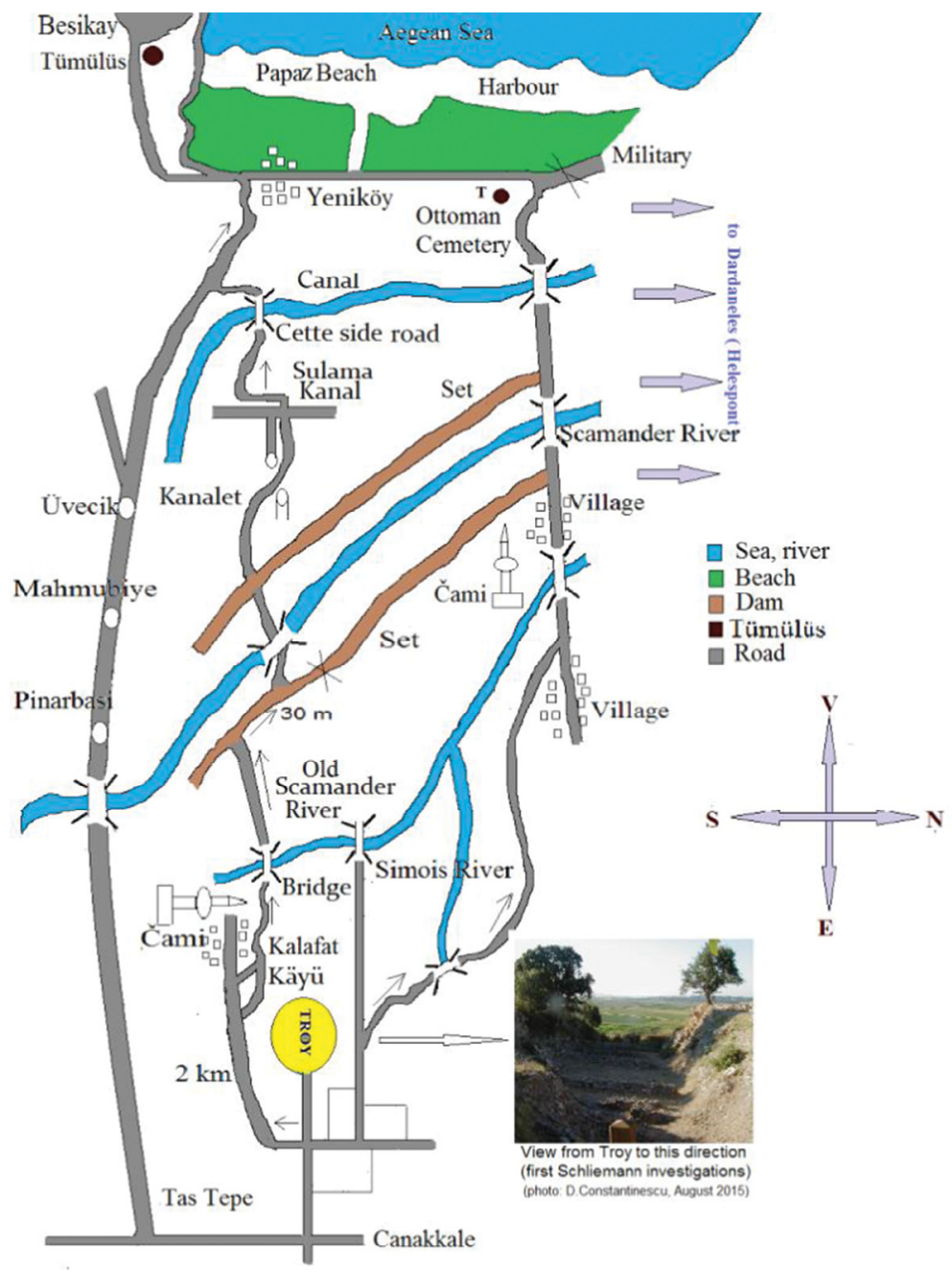

Figure 3: Troy reservation park (concept: Mustafa Aşkin; drawing: Geanina Setraru).

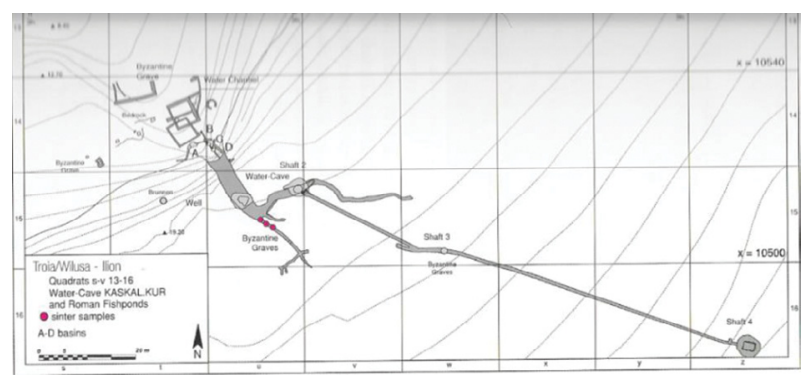

Figure 4: Plan of the water cave and underground tunnels located in the lower town of Ilion, Troy [2]. 


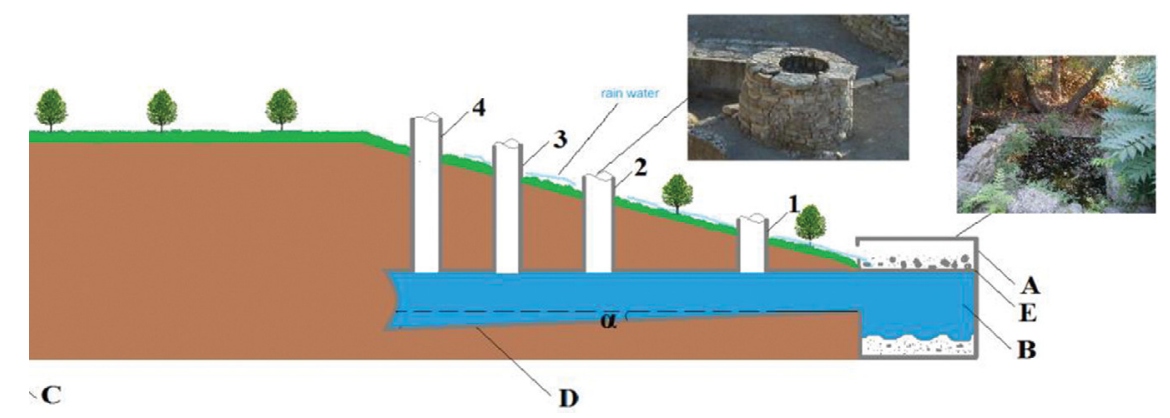

Figure 5: Water basin and underground tunnel at lower Troy. 1, 2, 3, 4 - shafts (4 till $17 \mathrm{~m}$ deep, 27.5 m altitude; A - basins 13 m; B - water; C - siliceous bedrock; D - tunnel; E - separator, filter; $\alpha-2-3$ deg. (M. Aşkin, D. Constantinescu; drawing: G.M. Setraru).

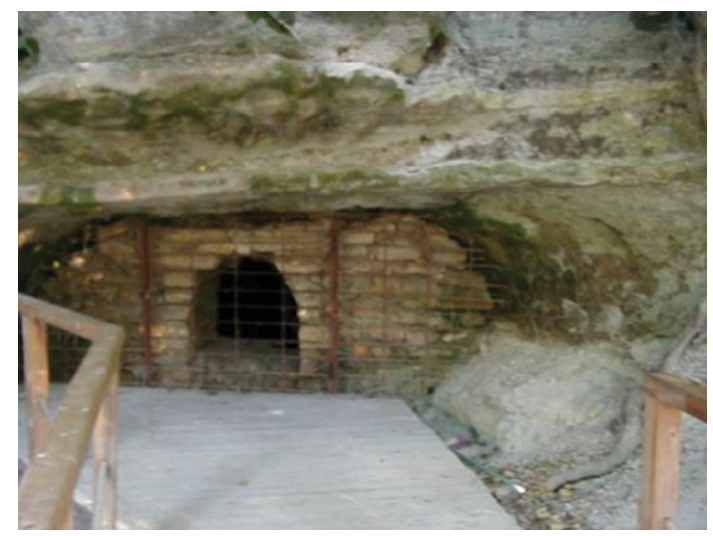

Figure 6: Entrance to the tunnel - water gallery (photo: D. Constantinescu, August 2015).

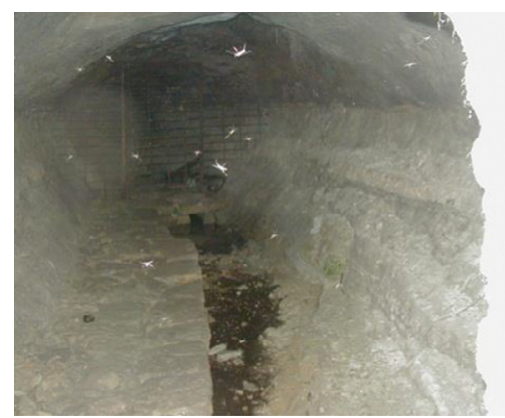

Figure 7: Interior of the tunnel (photo: D. Constantinescu, August 2015).

Having in view the aspect of the tunnel section, and the fact that it communicates between the fortress and the lower city, it is probable that the tunnel also had the function of being an 'escaping route' for some important inhabitants (Fig. 8). 


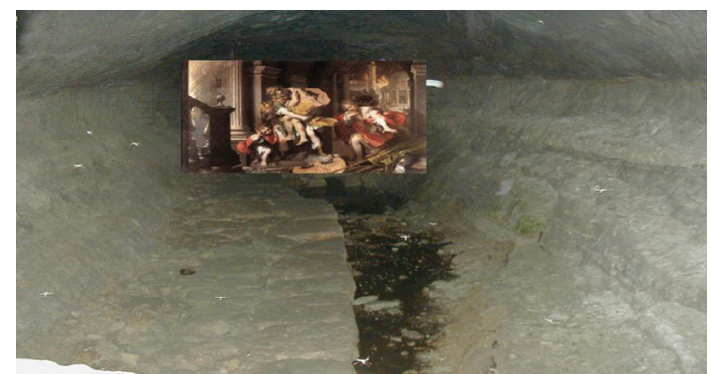

Figure 8: The tunnel was also an escaping route - 'Aeneas' Flight from Troy', by Federico Barocci.

\section{WATER RESOURCES SIMILAR TO TROY USED IN THE ROMAN HISTORICAL SITES ON DANUBE AND RHINE RIVERS}

These areas, including the territories along the Danube and the Rhine Rivers, were commanded by powerful empires, which have disappeared in time. The evolution, the increase and decrease till the disappearance of the Daco-Roman establishments along the Danube may explain not only the economic and climatic evolution, connected with the environmental situation, but also the used techniques, including the techniques for the water management. Structures similar to those in Troy were used 2500 years later by the Romans during construction of the cities and the citadels from Danube River till the Rhine River. Figures 9 and 10 present the water resources discovered at Augusta Raurica.

In the case of Augusta Raurica, normally an aqueduct net was used. The reservoir presented in Figs 9 and 10, which was recently discovered, was probably used for special situation. We can find a similar case at Sucidava and Ulpia Oescus, located on the Danube River $[10,11]$. In Fig. 11 a section of an internal aqueduct channel from Augusta Raurica on the Rhine River is presented.

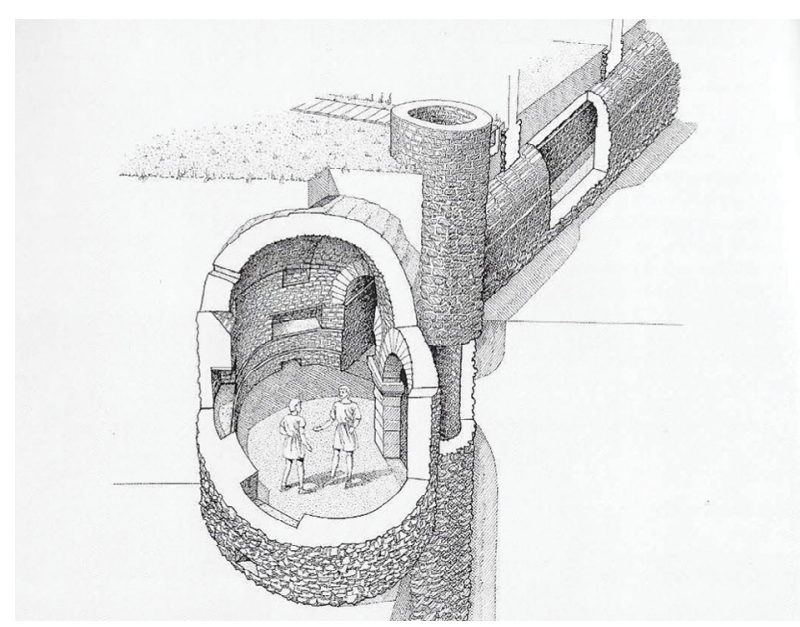

Figure 9: Proposed reconstruction of the underground water resource at Augusta Raurica [9] (drawing: M. Schaub). 


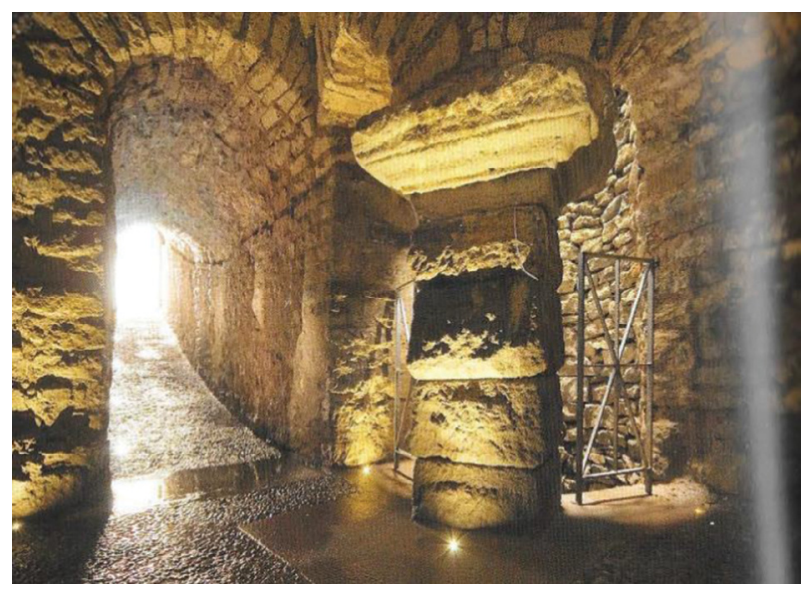

Figure 10: The present reconstruction of the underground Roman water source, 240 BC (photo: S. Schenker).

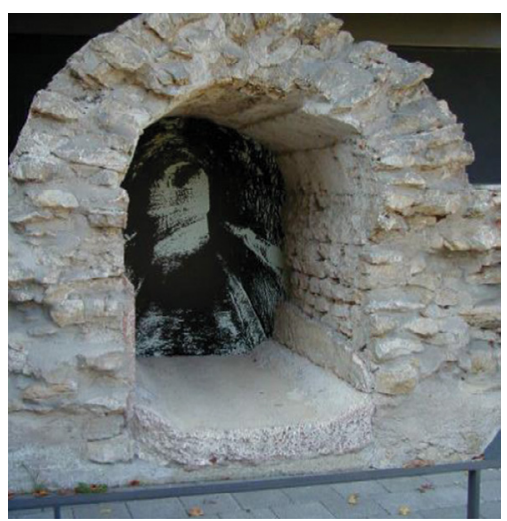

Figure 11: Aqueduct channel at Augusta Raurica (photo: D. Constantinescu, October 2011).

For the excavations and researches, it is necessary to apply new methods in order to discover the smallest indication about the investigated area. As already mentioned, regarding 'a bridge' between the Asian civilization and European civilization (Figs 1 and 2), the 'Anatolian Bridge' was a connector for many people who travelled from Asia to Europe and from Europe to Asia. These people left remarkable traces and had influenced the evolution of the history.

Following the remarks obtained till now from the large area, Mount Ida - Danube River - Rhine River [12, 8], some similitude needs to be taken into consideration. In Fig. 12 a proposal of the representation of the ancient underground water resource ('secret fountain') and the access tunnels is presented (length: $26 \mathrm{~m}$ ). It is a remarkable similitude with the underground resource from Augusta Raurica, but also with the tunnels from Troy. 


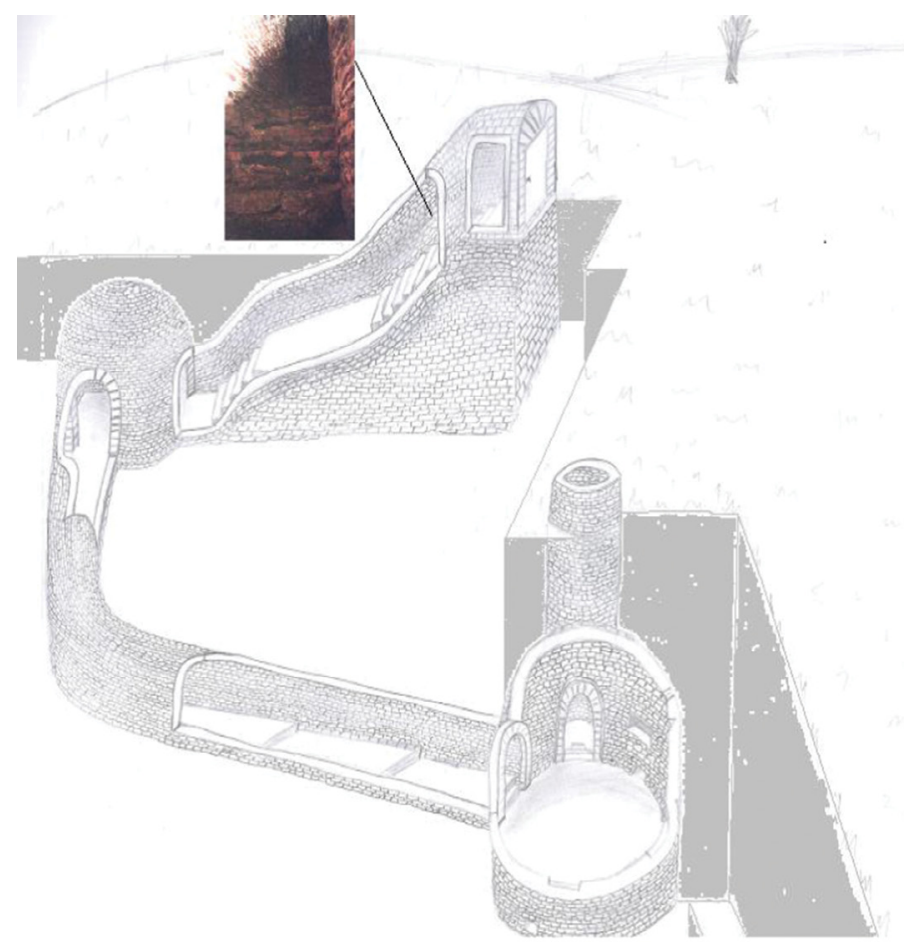

Figure 12: Underground water source from Sucidava, on the Danube (concept: D. Constantinescu; drawing: G.F. Gîrbăceanu, 2016).

\section{CONCLUSIONS AND COMMENTS}

One of the qualities most of the researchers in the branch of historical heritage need to have is optimism, the belief that they can say something about the past, simply based on the material remains and the deduction resulted from the analysis of these remains. Theories and histories regarding the evolution of populations, cities and fortresses, technologies, weapons or tools can be described, starting from classical archaeological discoveries or using new techniques of investigation. The example presented in this article regarding the usage of the water resources offers us information to know more about some aspects of the cultural evolution in the ancient sites. The conclusions we present regarding the connections between the ancient civilization and its influence on the present days may be accepted, criticized or refused, as Max Plank wrote, 'A scientific truth does not triumph by convincing its opponent and making them see the light, but rather because its opponents die and a new generation grows up that is familiar with it' [13].

If we just compare carefully Figs. 7, 9 and 12 it is possible to remark many similitudes, although thousands of years of time and thousands of miles of distance separate us from these constructions. We can consider this as a proof of heritage and the continuity of the civilizations.

Since nobody knows what really happened during the historical periods there will never be an end to researches. We can use the recent observations in order to start some new researches, followed by number of many others in the future. 


\section{ACKNOWLEDGEMENTS}

We wish to thank Mr Mustafa Aşkin, the professional guide from Troy Reservation Area, Hisarlîk. He is a very good and agreeable guide, offering much information that were difficult to discover on the field.

Many thanks to our co-workers Geanina Setraru and Gabriela Gîrbăcianu for their contributions and comments regarding the drawings of Sucidava and historical sites of Troy.

\section{REFERENCES}

[1] Constantinescu, D., Roman defence sites on the Danube River and environmental changes, Wessex Institute of Technologies publications, Structural Studies, Repairs and Maintenance of Heritage Architecture XIII, series volume 131, WIT press, pp. 563577, 2013, http://library.witpress.com/pages/PaperInfo.asp?PaperID=24844

[2] Korfmann, M., Troia/Wilusa, Çanakkale - Tübingen Foundation: Turkey, pp. 21-22, 28, 113, 2013.

[3] Tudor, D., Decouvertes archeologiques a Sucidva et dans les environs, A.O., XVI, 1936.

[4] Tudor, D., Une cite daco-romaine et Byzantine en Dacie, Publisher: Bruxelles Berchem: Latomus, 140 S., XXX S, Abb. 8, 1965.

[5] Cline, E.H., The Trojan War, published in USA by Oxford University Press: Oxford, pp. $1-3,2013$.

[6] Aşkin, M., Troy, published by Kartpostalcılık A.Ş.: Istanbul, Antalya Turkey, pp. 6-7, 2015.

[7] Schliemann, H., Bericht über die Ausgrbungen in Troja in den Jahren 1871 bis bis 1873 with a foreword of Manfred Korfman, Munih/Zurich, 1990.

[8] Hagendorn, A. \& Kamber, P., Unter Uns, Archeologie in Basel, Christoph Merian Verlag: Basel, pp. 149, 2008.

[9] Pfäffli Barbara, Archeologischer Führer durch Augst/Kaiseraugst, Werner Druck AG: Basel, pp. 56, 2010.

[10] Constantinescu, D., Roman defence sites on the Danube River and environmental changes, WIT press 2013, Structural Studies, Repair and Maintenance of Heritage Architecture XIII, volume 131, pp. 563-577, DOI: 10.2495/STR130471

[11] Constantinescu, D., Carlan, A.B., The ecological footprint and the evolution of some Roman sites on the Danube River, Defence Sites II, WIT press, Defence Sites Heritage and Future II, volume 143, pp. 3-15, 2014. DOI: 10.2495/DSHF140011

[12] Belard-Laur, R., Guide d'Augusta Raurica, 5-eme ed., Historische und Antiquarische Gesellschaft: Bâle, pp. 91-106, 1991.

[13] Bahn, Paul., Archeology, a very short introduction, Oxford University Press: Oxford, pp. 1-7, 2012. 